\title{
Fillers and the Development of Oral Strategic Competence in Foreign Language Learning
}

\author{
Nora M. Basurto Santos \\ María Magdalena Hernández Alarcón \\ Universidad Veracruzana, México \\ Irasema Mora PABLo \\ Universidad de Guanajuato, México
}

Received: 26 October 2014 / Accepted: 1 November 2015

ISSN: $1697-7467$

\begin{abstract}
A lot of research has been carried out on how students go about developing communicative competence when learning foreign languages. However, little do we know about how foreign language teachers help their learners to develop oral strategies that will enable them to cope with speaking problems on the fly and beyond the FL classroom. In this article we focused on a single oral communicative strategy that, we argue, has been neglected, in general, in foreign language classrooms. We present the findings of a research that focused on teaching fillers in FL classrooms in different teaching contexts and various FL classes.
\end{abstract}

Keywords: Fillers, foreign languages, communicative and strategic competence.

Las muletillas y el desarrollo de la competencia estratégica oral en el aprendizaje de las lenguas extranjeras

RESUMEN: Se ha investigado bastante sobre cómo los estudiantes desarrollan la competencia comunicativa durante el aprendizaje de lenguas extranjeras (LEs). Sin embargo, se sabe muy poco sobre cómo los profesores ayudan a sus estudiantes a desarrollar estrategias orales que les permitan enfrentar problemas que surgen en el momento de la comunicación y más allá del aula. En este artículo presentamos y discutimos los resultados de una investigación acerca de la enseñanza de las muletillas en clases de LEs en diferentes contextos educativos. Se concluye que la enseñanza de las muletillas ha sido descuidada en gran medida en los salones de lenguas extranjeras.

Palabras clave: Muletillas, lenguas extranjeras, competencia comunicativa y competencia estratégica.

\section{INTRODUCTION}

Learning to speak a foreign language (FL) requires a lot of effort, commitment, and developing the necessary awareness as each language has its own rules of interaction. This becomes especially true when this learning takes place in a context where the target language is not commonly used outside the FL classroom. It is now well-acknowledged that in order to communicate in any foreign language we need to develop not only the necessary 
linguistic competence but also the appropriate communicative competence as well (Holmes, 2013; Chaika, 2008). In other words, knowing how to pronounce words correctly, the use of appropriate grammar rules and an adequate vocabulary is not sufficient to speak a foreign language successfully. We also need to develop the knowledge that enables us to know what and how to say something according to whom we are speaking to, where we are speaking and what we are speaking about. That is, we need to develop communicative competence and this "involves not just linguistic knowledge, but cultural knowledge and interactional skills" (Bell, 2014: 3). Furthermore, to be able to speak a foreign language at ease, we need to develop speaking strategies. It goes without saying that all the aforementioned makes us realise that speaking is a very complex skill which deserves careful attention in the foreign language teaching and learning process as "there are rules in every culture as to when it is permissible to speak, when one must speak, and what style of speech is expected" (Chaika, 2008: 329). Teachers and learners of any foreign language need to bear in mind that all these aspects that come into play when we communicate in a foreign language are different across cultures and they are important considerations that we cannot overlook. If we are to become competent users of any foreign language it is necessary to be aware that "it is a question of knowing precisely how to do it in each language" (Idem.). Following this line of thought, it is our intention, in this paper, to address the issue of one simple, useful, though neglected speaking strategy: fillers. We will begin by describing what fillers are according to several well-known scholars. Then, we will briefly present the process and findings of a small-scale research carried out at the Language Faculty of the University of Veracruz that can be seen as the root of the research reported here. Then we will concentrate on presenting the findings of this second study that the authors of this article carried out some years later after the first study was conducted. Finally, drawing on the findings, we will present some pedagogical implications.

\section{REVIEW OF RELATED LITERATURE}

Fillers are discourse markers speakers use when they think and/or hesitate during their speech (Erten, 2014). According to Bygate (1987), fillers are "expressions like well, erm, you see, used in speech to fill in pauses". During oral interactions, speakers are highly likely to use expressions such as well, I mean, actually, you know, let me think to create a delay that enables them to carry on the conversation during times of difficulty. (Richards, and Schmidt, 2012: 220). Fillers are also known as pausing or hesitation phenomena which are "a commonly occurring feature of natural speech in which gaps or hesitations appear during the production of utterances." The commonest types of pauses are:

a) silent pauses, that is to say, silent breaks between words and

b) filled pauses which are gaps filled by such expressions as um, er, $\mathrm{mm}$.

It has been pointed out that people who speak slowly often use more pauses than people who speak quickly. It is also interesting to know that when people speak, up to $50 \%$ of their speaking time may be made up by pauses (Richards and Schmidt, 2012). Much of the research regarding fillers has been developed in the area of psycholinguistics. The first 
studies on $U h$ and $U m$ come from Maclay \& Osgood (1959). Other researchers added to this previous work and came to the conclusion that such fillers are called filled pauses (Tottie, 2011, p.174). "Clark \& Fox Tree (2002) called them fillers while Corley \& Steward (2008) referred to them as hesitation disfluencies" (Erten, 2014, p. 70). In research, it is difficult to determine when a filler is used as a marker for expressing uncertainty or hesitation. This process shows how complex the brain is and its mechanisms to express meaning in an utterance.

\subsection{The use of fillers}

In a normal conversation, people use fillers and hesitations to show a need of a word or simply to plan their next utterance. "There are a number of discourse markers either the English-speakers or the non-natives use for different purposes. "Well, Ehm, Uhm, How to say" are only some of them when they want to 'buy time' during their speech (Khojastehrad, 2012 , p.10). This is part of natural spontaneous speech. Fillers might actually signal that there is a cognitive process in the mind of the speaker, showing that the thinking process can derive in the creation of speech production. However, it is necessary to differentiate between filler words and pause fillers. According to O'Connell and Kowal (2005), citing Chafe (1980), hesitations do not interfere with the speaking; on the contrary, "pauses, false starts, afterthoughts, and repetitions do not hinder that goal, but are steps on the way to achieving it." (p. 462). Therefore, fillers help with the meaning of an utterance, they are not the meaning itself. Since interjections lack conceptual meaning, "when they appear alone their procedural meaning leads the hearer to activate different attitudinal concepts" (Wharton 2003, p. 60).

In regards to fillers, Biber et al. (2002) mention that conversation is normally a spontaneous activity, in which the participants are continually confronted with the "need both to plan and to execute their utterances in real time, on-line or on the fly".

Therefore, "normal dysfluency" is a trait of conversations. They further argue that it is very common for participants in a conversation to use pauses, hesitators and repetitions when "the need to keep talking threatens to run ahead of mental planning and the planning needs to catch up". These authors also differentiate between two types of fillers:

a) "a hold-up in delivery" which is a period of silence taken by the speaker to think what to say next;

b) a "filled pause" when the speaker utters a vowel sound, "with or without accompanying nasalization".

They add that these "filled pauses" are usually transcribed as: $u$ h and $u m$ in American English and as er and erm in British English. This difference in transcriptions does not imply a difference in pronunciation. In Tarone's (1980: 420) framework, pause fillers are production strategies rather than communication strategies, because production strategies "are not used for the primary purpose of negotiating meaning".

Finally, it has been acknowledged that pause fillers have been long dismissed as "stumbles or informal ways of stalling for time". However, much more recently these "humble pauses" have been the focused of linguist researchers in the Boston area of the United States as their studies have revealed that the subtle and varied functions of fillers are much wide ranging than thought (Peterson, 2015). 


\subsection{Teaching fillers in foreign language learning}

It has recently been acknowledged that "teaching how to hesitate in speaking has been a neglected part of teaching L2" (Erten, 2014: 71). Teaching fillers and their use is not an easy task in the language classroom. There are many factors that teachers and students need to consider. One of the main ones is the difference between the L1 and L2, as fillers are different in each language and students should be alerted of differences and peculiarities of interjections in their L1 and L2 (Aijmer, 2004). In order to approach students to the use of fillers, teachers can make use of videos, online chats, among others. However, teaching explicitly the use of fillers can be against the idea that fillers are part of a natural conversation. Some students might not even be aware of hearing or using a discourse marker even in their L1. According to Nakatani (2008) "it is reasonable to underline the importance of raising learners' awareness of strategies to raise their oral proficiency when they encounter problem in communication" (p. 78); therefore, fillers are a useful communication strategy. Teachers can help students to be conscious that, as listeners, they have a very active role in interaction because they bear the responsibility of interpreting messages and contributing to the avoidance of misunderstandings in a conversation by showing that they do or do not understand what their interlocutors say (Garcés Conejos and Bou Franch, 2002).

McCarthy (1998: 60) suggests that "any teacher wishing to incorporate insights in the spoken language has to decide the status of discourse markers in his classroom". In order to do this, the teacher needs to deploy a wide variety of strategies to make students aware of the different ways they can show hesitation or how they can incorporate meaning to what they want to say with words. In order to encourage students to increase their level of involvement in a conversation, it is important to make them aware that fillers can fulfill three essential functions (Garcés Conejos and Bou Franch, 2002: 91-92):

a) A cognitive function, in that the hearer shows the speaker that he is processing what she says.

b) A social function, as interjections signal involvement, affect or interest.

c) A discourse-regulatory function because they ratify the assignment of speaker- and hearer- roles and contribute to the shaping of discourse.

However, teaching these functions explicitly is not as easy as it might sound. Each teacher needs to find a way of practicing these functions, and encourage students to practice this outside the classroom as well.

\section{3. Мethod}

\subsection{Context and background to the current study}

In this section we briefly describe a study conducted many years ago by one of the researchers in the current study that can be taken as the root for the study reported in this article. In a nutshell, a small-scale was conducted with advanced students of a BA in English while they were giving oral presentations between five and ten minutes. These were recorded 
and later on transcribed. During the analysis of the data it became evident that students still seemed not to be able to speak in English for five minutes in a comfortable, natural and spontaneous way. It was very common for students to repeat Spanish words such as: bueno, este, ¿si?, entonces, etc. while they were speaking in English. Moreover, they seemed to be using these Spanish words in an unconscious and spontaneous way. These Spanish words are used as fillers in the spoken Spanish in Mexico. It was also noted that the use of Spanish fillers in their talks had a negative effect, since every time a student said este, bueno, etc., all his/her classmates started laughing, making the student-speaker lose concentration on what $\mathrm{s} /$ he was saying.

It became clear that these students needed to learn how and when to use English fillers as a speaking strategy. They could have been using fillers in English instead of the fillers in their mother tongue (L1). They did not seem to know how to rearrange their thoughts, nor did they know how to gain time to relax themselves when speaking. Moreover, the lack of use of English fillers when necessary made the students sound as if they were "reciting" their talks, as if they had learnt their "talks" by rote instead of speaking in a natural way. Students seemed to be in a hurry. They talked fast and gave the impression that they did so because they did not want to forget, not even one single word of what they had memorised. In the interview with the students these said that the usual way to prepare themselves to give a talk was to write a text about the chosen topic and then memorize it. They said that they did not dare to use only notes to help them remember what they wanted to say because they did not know how to arrange or rearrange their thoughts in their minds at the moment of speaking. Two students that had been using English fillers in their talks said that they had learnt these fillers by listening to their teachers and to people in movies. They added that it had taken two years after studying English at the Language School to notice this. Students complained that their teachers had never mentioned the use of fillers when speaking English. They thought that if they had been told about them, it would have helped them a lot with the oral tasks. Besides, these two students said that once they had picked up these er, erm, well, you see, I mean, etc. they were immediately able to use them. They also acknowledged that they had noticed that these expressions helped them feel relaxed and more comfortable when speaking, and even more importantly, they also felt that it had helped them to gain some fluency and confidence in using the target language (Basurto Santos, 2001.)

Having noticed that even though after so many years when this first study was carried out, students still seemed to be having the same problem, we decided to carry out a study on fillers but this time we were interested in finding out if other foreign language teachers, in other contexts apart from ours, had noticed this phenomenon and what they were doing or had done about this. In other words, we wanted to find out what foreign language teachers knew about the use of fillers and how they approached the task of teaching their students their use or not.

\subsection{Research Design}

Out of the different methods of data collection available to find out what FL teachers think or how they perceive the teaching and learning of fillers in the FL classroom (i.e. class observation, semi-structured interviews, video recordings, etc.) we decided to design an open-ended questionnaire (Bell and Walters, 2014) consisting of 20 questions. Resear- 
cher triangulation was employed in the validation process of this tool. Questions one to six were designed to obtain personal and professional information: the participants' names, the courses they taught, number of years teaching the foreign language, their nationalities, and their students' nationalities. The other 14 questions were the following:

7. What are the most used fillers in your language?

8. Which ones do you use when you speak?

9. Describe when you use them.

10. Have you noticed when you tend to use them more? (Describe).

11. Have you notice what function or role they play when you use them? (Describe)

12. Do you ever avoid using them? Why?

13. Do your students use fillers in your class? If so, which ones?

14. Have you noticed if there are occasions when your students tend to use them more than usual? Explain.

15. Have you taught your students the fillers that are used the most/ more frequently in the FL they are learning? Why?

16. Have you noticed if your students use fillers in their L1 when speaking in the FL/ L2? What happens if they do? Explain.

17. In the textbook that you are using, is there a lesson, section, or activity devoted to the teaching, use and practice of fillers?

18. Have you included the use of fillers in your FL classes? Why?

19. Do you think that students can acquire or learn how to use fillers in the FL on their own? Why?

20. Is there something you would like to add?

As we wanted to explore this topic beyond Mexican foreign language classrooms we decided to invite colleagues in other countries and teaching various foreign languages to answer the questionnaire. Taking into consideration that some of our participants work in other countries and that there was a time difference between Mexico and where they lived, we decided that the best and easiest way for them to take part in this study, was by having access to the questionnaire on line at any time. We then decided to use Survey Monkey as this electronic tool represented an opportunity to reach those foreign language colleagues working in other parts of Mexico and in other countries that it would have been impossible otherwise.

\subsection{Participants}

36 foreign language teachers took part in this research. Most of them were Mexicans (27) who taught English, French, Italian, and German to Mexicans and Spanish as a foreign language to students from many different countries and to speakers of many different mother tongues (L1). Two other participants were Spanish: one was teaching English to Spanish students and the other one was teaching Spanish as a foreign language in Germany to German, French, Turkish, and Russian students. Two Colombian teachers teaching French and English to Colombians answered the questionnaire too. One of the participants was form Belgium and he was teaching French to native speakers of Spanish in Mexico. An American 
participant taught EFL to Mexican students and a Mexican-German teacher taught German to speakers of Spanish. Finally, one English teacher was teaching English for Specific Purposes to multinational and multilingual students in the United Kingdom. The FL teachers' teaching experience ranged from five to over 30 years. Most of the participants had been teaching a foreign language or their L1 for over 15 years.

\section{Analysis and findings}

In this section we present the analysis and the main finding resulting out of the 14 remaining questions in our study. After reading the answers and analysing them very carefully three main categories emerged from the analysis: teachers' awareness of the use of fillers in their mother tongue (4.1), the use of fillers in everyday communication (4.2), and the teaching of fillers in FL classrooms or lack thereof (4.3).

\subsection{FL teachers' awareness of the use of fillers in the mother tongue}

It was very interesting to find out that all participants possessed a complete awareness regarding the use of fillers in their mother tongue. All of them, with no exception and regardless of their L1, expressed that they knew not only what fillers were used in their L1 but they shared which ones they used most of the time. In the table below a summary is offered of the results about this:

\begin{tabular}{|l|l|l|l|}
\hline Spanish & $\begin{array}{l}\text { Mexico: Este, o sea, wey, } \\
\text { mmm, ok, ¿ok?, pues sí, } \\
\text { ajá, a ver, ¿me explico?, } \\
\text { ¿si?, ¿no? órale, eh, } \\
\text { ¿viste?, bueno, haz de } \\
\text { cuenta, es que, eso, fijate, y } \\
\text { este, estedem. }\end{array}$ & $\begin{array}{l}\text { Colombia: si, ya, ok, } \\
\text { entonces, eeehh, pues, ¿me } \\
\text { hago entender?, claro, bueno, } \\
\text { a ver, digamos, ¿cierto? }\end{array}$ & $\begin{array}{l}\text { Spain: ¿sabes?, } \\
\text { ¿entiendes?, ¿no?, } \\
\text { pues, es decir, pues } \\
\text { nada, eh, vale, ok, } \\
\text { ¿me explico?, digo yo, } \\
\text { Lavín, ¿sí o qué? }\end{array}$ \\
\hline French & $\begin{array}{l}\text { Bien, bon, euh, donc, alors, ben, j'veux dire, tu vois, mmh, allez, comment dire, } \\
\text { comment on dit?, au fait, á propos, dis, ça va? }\end{array}$ \\
\hline English & Erm, um, er, I mean, right, ok, now, well, uhu, you know?, so \\
\hline
\end{tabular}

Fillers used in Spanish, French, and English.

It was evident that the Spanish speakers were the ones who seemed to have more words, expressions, or sounds used as filled pauses in comparison to English and French-speaking participants. It might be helpful to bear in mind that if we are teaching Spanish speakers to learn a FL, our students might be used to saying or relying on many speaking expressions used as an oral strategy in their L1 so it would be natural to assume that they are very likely to try to transfer this knowledge to the new FL they are learning or acquiring. 
It is also worth highlighting that even though the Spanish speakers shared most of the fillers used in their L1, there were certain fillers used only in Mexico (e.g. wey, híjole, órale), or only in Spain (e.g. pues nada, Lavín), and some that seemed to be found only in the spoken Spanish of Colombia (¿cierto?, ¿me hago entender?). This showed how important is to be aware of the cultural aspect of fillers. This finding is in line with Aijmer (2004) who already noted, that FL teachers need to make their students aware that there are differences between fillers used in each language and of the importance of helping FL students to become aware of differences and peculiarities of fillers in their L1 and L2.

\subsection{The use of fillers in every day communication}

Not only were the participants able to articulate their knowledge of the fillers used in their L1 but they also expressed very clearly how pervasive this oral strategy appeared in their everyday conversations. Moreover, they mentioned what the different functions the use of fillers played in their everyday speech. For example, Laura ${ }^{1}$ said that for her:

fillers have a very practical use in everyday conversations. For example, I use them, I use short phrases, or I repeat some words, or stretched the last sound of a word like yessss [siiiii] while I am looking for the exact word I want to say or the idea I want to express but I cannot find it quickly. It is a resource, a tool that I use. ${ }^{2}$

In Laura's everyday communication, fillers play a very important role. She not only is fully aware of all the different fillers she commonly uses but she also knows what role they play in her speech. It is clear that she uses them to "buy time" while she is trying to find the exact words to convey her messages in exactly the way she wants to.

Among the most common functions identified by our participants concerning their use of fillers in their everyday conversations are: "fill in spaces in conversations", "when I am expecting feedback from the hearer", "when I am nervous" "to organize my speech", "when I feel insecure about what I am talking about". It is natural to assume that if competent users of an L1 need to use fillers to meet all these different functions (i.e. keep the conversation going, signaling the hearer that something is expected, take some time needed), learners of foreign languages are even more likely to go to go through these same experiences and more frequently as they are still in the process of developing fluency and accuracy in their oral interactions inside and outside the FL classrooms. One of the participants, Greg, mentioned a very interesting function that he had realized that his use of fillers performed:

I use fillers when I want to signal that I want to continue with my turn in a conversation.

For Greg, fillers seemed not only to serve the purposes that all other participants mentioned but this nuanced use of fillers, to hold the floor in a conversation, is in line with what has been found in Liberman's research when he asserts that fillers have wide-ranging

\footnotetext{
${ }^{1}$ All participants' names are pseudonyms.

${ }^{2}$ All quotes were translated into English by the authors of this article.
} 
applications than what has been thought before (in Peterson, 2015). In other words, this use of fillers is not about the more common use of this oral strategy but it signals a developed strategic competence used in conversations among competent users of languages: not to let your interlocutor take or "steal" the floor before you finish your turn.

\subsection{The teaching of fillers in FL classrooms or lack thereof}

The third category that emerged from the analysis of the data obtained through the open-ended questionnaire has to do with what our participants expressed concerning the teaching of fillers in FL classrooms. All teachers but one said that the textbooks they had to follow in their foreign language lessons did not include even an activity to focus the students' attention on the use of fillers as an oral strategy or to develop their strategic competence when interacting in the FL. The only participant who was the exception mentioned that she sometimes concentrated on fillers as "fillers are part of my course when I teach sociolinguistics". As can be noted, in fact, her students read about fillers as part of a course on sociolinguistics which is very different from learning or practising to use them as an oral strategy when speakers may find difficulties while taking part in oral presentations or conversations in the foreign language.

Regarding whether our participants included some extra activities to help their learners use fillers in the foreign language when they felt they needed, most of them answered that they had not. A few participants reported that they had just mentioned to their students when they had explicitly asked about them. When asked about if she included the use of fillers in her FL lessons and why, Claire admitted that:

No, not really. It's not that I have explicitly devoted a lesson or some activities to the use of fillers in my FL classes. I use them with my students because it is the way I speak with them. I think that it would be impossible to eliminate them completely from the way I speak.

Claire's answer illustrates very clearly what most participants expressed about the teaching of fillers in foreign language classes. Among our participants, in general, there is not an awareness of the need to teach fillers explicitly to their learners for various reasons: "No, students can pick them when they live abroad", "I don't think it is necessary", "If they ask me about them". These views about the teaching of fillers in FL classrooms are striking considering that they all admitted that fillers featured almost always in their everyday speech in their L1.

Finally, among the answers to the final question, when participants were asked if they wanted to add something, we found that some teachers started to reflect on the teaching of fillers or lack thereof in FL classrooms. For example, according to Charles "It is necessary to train FL teachers on this topic". Julia wrote: "you have made me think in something new". Ralph said that "it would be interesting to know how people use fillers in their different L1s. This could help us decide how important and useful they are for non-native speakers to learn them". 


\section{Conclusions ANd PEDAgogical implications}

The findings of this research are very enlightening for foreign language teachers in general, since some pedagogical implications can be drawn from this small-scale study. First of all, it can be concluded that not only the teaching of fillers have been neglected in the FL textbooks but FL teachers, in general, have overlooked or taken for granted that just because fillers are used in the students' L1, they will naturally develop their use in the foreign language that they are learning. However, as McCarthy (1998) rightly pointed out, FL teachers need to deploy a wide variety of strategies to make students aware of the different ways they can show hesitation or how they can incorporate meaning to what they want to say with words. If foreign language teachers are to encourage their learners to increase their level of involvement in a conversation in a confident and spontaneous way, it is important to make them aware that fillers can fulfill essential functions in their development of oral skills that are deemed necessary in everyday interactions when using the FL in the classroom and/or in real contexts where they are very likely to encounter themselves later on. Further, FL teachers should never underestimate the teaching of any strategy that may contribute to our learners' language improvement, no matter how insignificant they might appear. It is important to bear in mind that all language teachers are competent speakers of our mother tongue and as such we are aware of the use and the importance of knowing how and when to use fillers. As experienced speakers of a foreign language we also know that we use fillers since they are a very useful speaking strategy which helps us sound "normal" as Bygate (1987) has rightly pointed out.

We would like to mention that teaching our students how and when to use fillers or hesitation strategies to "buy time", (be it to rearrange their thoughts, to get relaxed, to signal that they want to continue speaking), it is also important to warn them about the overuse of fillers. As proficient speakers of more than one language, we know that overusing fillers might be counterproductive as we might appear as not being very competent users of the FL or appear to be unable to get our messages across in a clear and efficient way.

Finally, we found out that sometimes there are "small things" that our FL students need to be made aware of and that we foreign language teachers tend to overlook or take for granted thus forgetting that these small things can make $a$ big difference, especially to students who are still in the process of learning to develop not only communicative competence but strategic competence when speaking in the FL as well.

\section{REFERENCES}

Aijmer, K. (2004). "Interjections in a Contrastive Perspective", in Edda, W. (ed.), Emotion in Dialogic Interaction: Advances in the Complex. Philadelphia: John Benjamin, 99-120.

Basurto Santos, N.M. (2001). "Why do students . . . este . . use fillers. . . eh. . . in Spanish when speaking. . .bueno . . in English?", in Avatar. Revista de la Facultad de Idiomas, UV, 11/12: 29-35.

Bell, J., and Waters, S. (2014). Doing your Research Project: A Guide for First Time Researchers (6th ed.). Berkshire, UK: OUP.

Biber, D. J., Geoffrey, L., Conrad, S., \& Finegan, E. (2002). Longman Grammar of Spoken and Written English. London: Longman. 
Fillers and the...

Bygate, M. (1987). Speaking. Oxford: Oxford University Press.

Chaika, E. (2008). Language the Social Mirror. (4th ed.). Boston: Heinle.

Clark, H. H. and Fox Tree, J. E. (2002). "Using Uh and Um in spontaneous speaking", in Cognition, 84: 73-111.

Corley, M. and Stewart, O. W. (2008). "Hesitation disfluencies in spontaneous speech: The meaning of um", in Language and Linguistics Compass, 2,4: 589-602.

Erten, S. (2014). "Teaching Fillers and Students' Filler Usage: A Study Conducted at ESOGU Preparation School", in International Journal of Teaching and Education, 2,3: 67-79.

Garcés Conejos, P. and Bou Franch, P. (2002). "A Pragmatic Account of Listenership: Implications from Foreign/Second Language Teaching”. Revista Alicantina de Estudios Ingleses, 15: $81-102$.

Holmes, J. (2013). An Introduction to Sociolinguistics (Learning About Language). (4th ed.). NY: Routledge.

Khojastehrad, S. (2012). "Hesitation strategies in oral L2 test among Iranian students-shifted from EFL context to EIL", in International Journal of English Linguistics, 2,3: 10-21.

Maclay, H. and Osgood, C. (1959). "Hesitation Phenomena in Spontaneous English Speech", in Word, 15: 19-44.

McCarthy, M. (1998). Spoken Language and Applied Linguistics. Cambridge: CUP.

Nakatani, Y. (2008). "The effects of awareness-raising training on oral communication strategy use", in The Modern Language Journal, 89: 76-91.

Nunan, D. (1999). Second Language Teaching \& Learning. Boston: Heinle \& Heine Publishers.

O'Connell, D. C. \& Kowal, S. (2004). "The History of research on the filled pause as evidence of The Written Language Bias in Linguistics (Linell, 1982), in Journal of Psycholinguistic Research, 33,6: 459-475.

Peterson, B. "How 'ums, and 'ers' are changing Bostonian Spanish" in The Boston Globe, September 27, 2015.

Richards, J. \& R. Schmidt. (2012). Longman Dictionary of Language Teaching \& Applied Linguistics. Essex: Longman.

Stubbs, M. (1983). Discourse Analysis: The Sociolinguistic Analysis of Natural Language. Oxford: Basil Blackwell.

Tarone, E. (1980). "Communication strategies, foreigner talk and repair in interlanguage", in Language Learning, 30: 417-431.

Tottie, G. (2011). "Uh and Um as sociolinguistic markers in British English", in International Journal of Corpus Linguistics, 16, 2: 173-197.

Wharton, T. (2003). "Interjection, Language, and the 'Showing/Saying' Continuum", in Pragmatics and Cognition, 11: 39-91. 